\title{
The Role of Pea (Pisum sativum) Seeds in Transmission of Entero-Aggregative Escherichia coli to Growing Plants
}

\author{
Leonard S. van Overbeek *, Carin Lombaers-van der Plas and Patricia van der Zouwen \\ Wageningen Plant Research, Wageningen University and Research (WUR), 6700 AB Wageningen, \\ The Netherlands; carin.lombaers@wur.nl (C.L.-v.d.P.); patricia.vanderzouwen@wur.nl (P.v.d.Z.) \\ * Correspondence: leo.vanoverbeek@wur.nl
}

Received: 6 July 2020; Accepted: 19 August 2020; Published: 21 August 2020

check for updates

\begin{abstract}
Crop plants can become contaminated with human pathogenic bacteria in agro-production systems. Some of the transmission routes of human pathogens to growing plants are well explored such as water, manure and soil, whereas others are less explored such as seeds. Fenugreek seeds contaminated with the entero-hemorrhagic Escherichia coli O104:H4 were suspected to be the principle vectors for transmission of the pathogen to sprouts at the food-borne disease outbreak in Hamburg and surrounding area in 2011. In this study we raised the questions of whether cells of the entero-aggregative E. coli O104:H4 strain 55989 is capable of colonizing developing plants from seeds and if it would be possible that, via plant internalization, these cells can reach the developing embryonic tissue of the next generation of seeds. To address these questions, we followed the fate of strain 55989 and of two other E. coli strains from artificially contaminated seeds to growing plants, and from developing flower tissue to mature seeds upon proximate introductions to the plant reproductive organs. Escherichia coli strains differing in origin, adherence properties to epithelial cells, and virulence profile were used in our experimentation to relate eventual differences in seed and plant colonization to typical E. coli properties. Experiments were conducted under realistic growth circumstances in greenhouse and open field settings. Entero-aggregative E. coli strain 55989 and the two other E. coli strains were able to colonize the root compartment of pea plants from inoculated seeds. In roots and rhizosphere soil, the strains could persist until the senescent stage of plant growth, when seeds had ripened. Colonization of the above-soil parts was only temporary at the start of plant growth for all three E. coli strains and, therefore, the conclusion was drawn that translocation of $E$. coli cells via the vascular tissue of the stems to developing pea seeds seems unlikely under circumstances realistic for agricultural practices. Proximate introductions of cells of E. coli strains to developing flowers also did not result in internal seed contamination, indicating that internal seed contamination with $E$. coli is an unlikely event. The fact that all three E. coli strains showed stronger preference for the root-soil zones of growing pea plants than for the above soil plant compartments, in spite of their differences in clinical behaviour and origin, indicate that $E$. coli in general will colonize root compartments of crop plants in production systems.
\end{abstract}

Keywords: entero-aggregative Escherichia coli; Pisum sativum; EHEC; seed; plant production system; human pathogen; E. coli O104:H4

\section{Introduction}

Contamination of crop plants by human pathogenic bacteria can already occur at plant growth in the field or greenhouse. The transmission routes via which these pathogens are transmitted to crop plants are not always clear, but contamination can occur via (fresh) manure application to soil, upon 
irrigation, or via human handling with contaminated materials, equipment or machines. Alternative transmission routes of human pathogens to plants are less explored and one of these can be via starting materials such as seeds.

Seeds used for production of sprouts were reported to be contaminated with human pathogens such as Escherichia coli, especially the enterohemorrhagic variants thereof (EHEC), Salmonella enterica, Bacillus cereus, Listeria monocytogenes, Staphylococcus aureus and Yersinia enterolitica [1]. Human pathogens of different strains of S. enterica, E. coli O157:H7 and E. coli O104:H4 were shown to attach to fenugreek, alfalfa, lettuce and tomato seeds within $5 \mathrm{~h}$ upon exposure [2]. Furthermore, it was shown that $S$. enterica and E. coli O157:H7 strains could persist on butterhead lettuce seeds for two years and after that time, both pathogens were still able to proliferate on germinating seeds [3]. From these cases it is clear that seeds can become contaminated with human pathogens and that contaminated seeds can pose serious risks for human health at primary production of freshly consumed vegetables and fruits.

The largest outbreak related to consumption of produce was in Hamburg and the surrounding area (Germany) in 2011 upon consumption of fenugreek sprouts. Most likely, it was the fenugreek seeds used for sprout production that were the source of the contaminating agent, E. coli O104:H4, although the pathogen could never be traced back in the seed batches that were used for sprout production [4]. However, the outbreak strain was exceptional as it did not belong to the more 'classical' EHEC outbreak strains such as E. coli O157:H7, but instead to the group of entero-aggregative E. coli [5]. Commonly, E. coli O104:H4 has a human reservoir and is endemic in central Africa, but has never been reported before to be carried over via plants to humans. Entero-aggregative E. coli strains are dissimilar from the more common EHEC serotypes that carry the eae gene on a plasmid of which the product, the outer membrane protein intimin, is responsible for causing the typical intimate attachment to epithelial cells. Escherichia coli O104:H4 do not produce the intimin protein, but instead form a typical stacked brick-like cell structure on the intestinal cells and from there the bacterial cells release Shiga toxin into the human gut [6]. The aggregative adherence fimbriae (AAF), expressed from a gene located on the pAA plasmid, are responsible for this typical stacked brick bacterial cell feature, enabling entero-aggregative $E$. coli strains to colonize the intestinal mucosa layer. It is a question that still needs to be addressed whether these differences in bacterial attachment to human epithelial cells might also be responsible for eventual different behaviour of E. coli strains on seeds and on, or inside, plants emerging from seeds.

Plants can be colonized by E. coli and persistence near plants, on their outside surface and even internally, by different $E$. coli strains has been reported over time [7-9]. Escherichia coli strains show chemotactic responses to plants and can resist local plant immune responses in the form of oxidative stress $[10,11]$ and it is able to protect itself against osmotic stress by conversion of plant derived choline to betaine [12]. Escherichia coli strains were found at different locations in multiple plant species and most commonly E. coli showed preference for the root zones and rhizosphere soils [13-15]. However, soil management also played an important role in persistence of E. coli in agricultural systems as the type of soil amendment on E. coli persistence was stronger than presence or absence of maize roots [16]. Damaging of seminal roots and root hairs, either mechanically, or caused by the phytopathogenic root-knot nematode Meloidogyne hapla, did not result in significant higher root internalization by E. coli, with respect to the undamaged control treatment [17]. Most of the described studies in plants were undertaken with E. coli O157:H7 and occasionally with E. coli K12, but not so often with strains belonging to other E. coli types, such as entero-aggregative E. coli strains to which E. coli O104:H4 belong to.

Escherichia coli is a complex species group and in the past this group was classified on the basis of their colonization behaviour in warm-blooded animals and on the clinical symptoms derived from oral ingestion of pathogenic strains. However, the E. coli species complex consists of strains whose lifestyles diverge from pathogens to commensals, and their capacity to persist and colonize ecological niches outside the colon is remarkable [18]. Escherichia coli genomes are flexible, allowing strains easily to adapt to local reigning circumstances [19-21]. Therefore, it should be accounted for that E. coli strains present 
in soil ecosystems are distinct from the ones in animals [22,23]. Human pathogens taxonomically related to E. coli, such as Salmonella enterica, also can colonize plants and even can communicate with plant cells $[7,24,25]$. Plants must be recognized as 'alternative' habitats for food-borne enteric bacteria [26] and Enterobacteriaceae, the taxonomical family to which E. coli and S. enterica belong to, are common inhabitants of plants. Particular groups of endophytes and phytopathogens also belong to this group $[21,27]$ and therefore Enterobacteriaceae must be considered as an important component of the plant microbiome. Microbiomes of plants will form an important barrier against invasions of human pathogens in plant production systems and Enterobacteriaceae also play an important role in the defence of plants against invasive micro-organisms [28-30]. Human pathogens invasive to plants may acquire genetic information from plant-indigenous Enterobacteriaceae making them better adapted to circumstances locally reigning in, and near plants [21,31].

In this study we raise the questions as to whether E. coli O104:H4 is capable to colonize developing plants from seeds and if it would be possible that, via plant internalization, E. coli cells could reach the embryonic tissue of developing seeds. If the last is possible, then it would mean that, in the worst case, E. coli O104:H4 could persist in seeds for over many generations and even could be protected from common seed surface disinfection treatments because of the protection provided by the seed coat. Application to plant reproductive organs with the endophyte strain Paraburkholderia phytofirmans PsJN lead to internal seed contamination resulting in dissemination of this strain to next generations of plants [32]. Via experimentation, we explored the possibility if this could also be the case for E. coli. To address this question, we followed the fate of strain 55989 and of two other E. coli strains from artificially contaminated seeds to growing plants, and from developing flower tissue to mature seeds upon proximate introductions to the plant reproductive organs. We chose for Afila type (dwarf) pea, Pisum sativum, as model plant because of its fast and robust growth under variable circumstances, but also because of the size and smooth surface structure of the seeds making them easy to handle under the applied experimental circumstances. Experiments were conducted under realistic growth circumstances in greenhouse and open field settings. Escherichia coli strains differing in origin (plant versus human), adherence properties to epithelial cells (aggregative adherence fimbriae versus surface protein intimin), and virulence profile (possession of EHEC virulence genes or not) were used in our experimentation to relate eventual differences in seed and plant colonization to typical E. coli properties.

\section{Materials and Methods}

\subsection{Escherichia coli Strains}

Entero-aggregative E. coli O104:H4 strain 55989 was isolated in the period between 1996 and 1999 from faeces of a patient suffering from human immunodeficiency virus (HIV) and persistent diarrhoea from the Central African Republic [33]. This strain was used in all experiments conducted in this study. Two other strains were used for comparison in pea plant colonization: extended spectrum beta lactamase E. coli strain 0611 and Shiga toxin producing E. coli O150:H2 strain N112 (Table 1). Strain 0611 was obtained from morning glory leaves imported as culinary herb from Thailand [34], whereas strain N112 was obtained from grass plants taken from a meadow land located in the neighbourhood of Nijkerk, the Netherlands [23]. All E. coli strains were grown overnight under shaking (180 RPM) at $37^{\circ} \mathrm{C}$ in Luria Bertani broth (LB: Tryptone, $10 \mathrm{~g}$; yeast extract, $5 \mathrm{~g}$; NaCl, $10 \mathrm{~g}$; dissolved in one L water and standard autoclaved for $20 \mathrm{~min}$ at $121^{\circ} \mathrm{C}$ ). Thus obtained late exponential cells were harvested by centrifugation and cell pellets were washed twice in Ringer solution ( $\frac{1}{4}$ strength Ringers, OXOID BR0052, Basingstoke, UK; one tablet dissolved in $0.5 \mathrm{~L}$ demineralized water followed by autoclaving). Prior to experimentation, optical densities at $600 \mathrm{~nm}\left(\mathrm{OD}_{600}\right)$ of suspensions were measured and retrospectively validated by colony forming unit (CFU) enumeration onto Brilliance E.coli/coliform selective agar (BECSA, OXOID CM1046, Basingstoke, UK) medium without further amendments for strain 55989, or onto BECSA amended with $1 \mu \mathrm{g}$ per $\mathrm{ml}$ of cefotaxime for strain 0611 or onto CHROMagar $^{\mathrm{TM}} \mathrm{O} 157$ (CHROMagar ${ }^{\mathrm{TM}}$, Paris, France) for strain N112. 
Table 1. E. coli strains used in this study.

\begin{tabular}{ccccc}
\hline Strain & Serotype & Characteristics & Origin & Reference \\
\hline 55989 & O104:H4 & Entero-aggregative E. coli & human faeces & {$[33]$} \\
N112 & O150:H2 & STEC (stx1, 2, hlyA, eae $)$ & grass shoots & {$[23]$} \\
0611 & not identified & ESBL $\left(\right.$ chr: bla $a_{\text {CTX-M-15 qnrS1) }}$ & morning glory & {$[34]$} \\
\hline
\end{tabular}

\subsection{Pea Seed Treatment with E. coli}

The same seed batch of Afila type (dwarf) pea (Pisum sativum) were used throughout all experiments. Microbial analysis of seeds revealed a contaminating fungal load in the seed lot and, therefore, seeds were disinfected with $1 \%$ chlorine solution for $10 \mathrm{~min}$. As a result of disinfection, the germination rate of the seeds increased from $84.8 \%$ to $93.2 \%$. Disinfected seeds were, therefore, used in all further experiments.

For setting up a standardized seed inoculation protocol, the minimal exposure time and cell density required for efficient attachment of $E$. coli cells to the seed surface, performed with strain 55989 only, were established. For establishment of the minimal exposure time, seeds were exposed for 1 , 5, 10, 30 and 60 min to exponentially-grown $\log _{10}(\log ) 5.59$ E. coli strain 55989 cells per $\mathrm{mL}$ and upon exposure, treated seeds were stored for $24 \mathrm{~h}$ at room temperature, after which seeds were rinsed twice in sterile Ringer solution to remove loosely attached strain 55989 cells from the seed surface. For establishment of the minimal effective density of strain 55989 cells for seed treatment, seeds were exposed for one $\mathrm{h}$ to a range of inocula, 10-fold increasing in densities, starting from Log 0.37 to up to Log 7.37 cells per $\mathrm{mL}$, using sterile water as negative control. After exposure, treated seeds were stored for $24 \mathrm{~h}$ at room temperature, after which seeds were washed two times in sterile Ringers solution and $100 \mu \mathrm{L}$ of washing solutions and smashed pea seed extracts (made by hammering one seed for $30 \mathrm{~s}$ in a Bioreba bag [Bioreba AG, Reinach, Switzerland] with three $\mathrm{mL}$ Ringer solution) were plated onto BECSA, and plates were incubated under standard conditions, i.e., for $16 \mathrm{~h}$ at $37^{\circ} \mathrm{C}$ for colony formation. For inactivation of strain 55989 cells attaching to the pea seed surface, three different disinfection solutions; i.e., silver/copper (AMS), chlorine dioxide and hypochlorite, as previously described for lettuce leaf decontamination [35], were applied. Therefore, $10 \mu \mathrm{L}$ droplets containing Log 5.79 strain 55989 CFUs were placed onto seed surfaces and incubated for one $h$ at room temperature. Upon incubation, droplets were removed with a pipet tip and treated seeds ( $n=5$ per treatment) were incubated for one min in the different disinfecting solutions using sterile water as control. Upon incubation, liquids and smashed pea extracts were plated onto BECSA, and plates were incubated.

For experimentation in greenhouse and fields, two types of seed inoculation methods were applied: (1) local seed inoculation using $10 \mu \mathrm{L}$ droplets with $E$. coli cells (drop inoculation) placed on the seed surface and (2) submergence of seeds in an E. coli cell suspension (seed submergence). For drop inoculation, a single droplet with between Log 7.2 and 7.4 cells per $10 \mu \mathrm{L}$ were placed on the seed surface and treated seeds were kept in a laminar flow cabinet at room temperature for one $h$, after which droplets were removed using a sterile pipet tip. For submergence, seeds were incubated for one $\mathrm{h}$ in a laminar flow cabinet at room temperature in a washed $E$. coli cell suspension with densities between Log 9.2 and 9.4 cells per mL. Seeds from all treatments were collected, washed twice in Ringer solution and dried overnight $(16 \mathrm{~h})$ in a laminar flow cabinet. For the second field study, conducted in 2016 and executed with strain 55989 only, submerged seeds were washed, dried and stored in a desiccator for $48 \mathrm{~h}$ at constant relative air humidity (RAH) of $36 \%$ or $96 \%$, or stored for $35 \mathrm{~d}$ in a fridge at $4{ }^{\circ} \mathrm{C}$, at ambient RAH. Relative air humidities in the desiccators was maintained at $36 \%$ by using a saturated $\mathrm{CaCl}_{2}$ solution and at $96 \%$ by using demineralized water.

\subsection{Comparison of Three Different E. coli Strains in Pea Plant Colonization}

A plant colonization study with three E. coli strains $(55989,0611$, N112) in developing pea plants was performed in the greenhouse. For that purpose, seeds were treated with the three strains separately or with water (control) via submergence and drop inoculation $(n=5$ per treatment, three strains 
plus control and two inoculation types, leading to a total of eight treatments). A total of 160 treated, and 80 non-treated (see later) seeds were planted into standard potting soil and treated seeds were allowed to germinate in the dark for three $\mathrm{d}$ followed by subsequent plant growth at a day/night regime of $8 \mathrm{~h}$ darkness at $18{ }^{\circ} \mathrm{C}$ and $16 \mathrm{~h}$ light at $22^{\circ} \mathrm{C}$ with a constant air humidity of $70 \%$. Densities of the different $E$. coli strains, using water-treated seeds as controls, were determined by plating onto the agar medium respective for each strain and on BECSA for control seeds, for eventual presence of indigenous E. coli in seeds. Based on different growth stages after 8, 19, 34, 50, 62 and $80 \mathrm{~d}$, plants of all treatments were analysed at different locations for the eventual presence of (inoculated) E. coli. On day 8 , the primary roots, cotyledon and epicotyl were analysed, whereas at days 19, 34 and 62 roots, stem base (stem $0.5 \mathrm{~cm}$ above the soil until the first true leaf pair) and top stem (stem part between the fourth and fifth true leaf pair) were analysed. At 80 days after sowing (DAS) seeds were collected for later analysis on eventual presence of E. coli. Primary roots, cotyledons and epicotyls at day 8 were taken from plants and transferred to Bioreba bags containing one $\mathrm{mL}$ Ringer solution and extracts were made by hammering as described before for treated seeds. These extracts were then serial diluted 10-fold, and non-diluted and diluted samples were plated onto the agar medium respective for each strain and on BECSA for extracts from control plants, and all plates were incubated under standard conditions. Root and stem (stem base and top) samples, taken at 19, 34 and 62 days after sowing (DAS), were transferred to Bioreba bags with three $\mathrm{mL}$ Ringer solution after which extracts were made. Non-diluted and tenfold serial diluted samples were then plated onto the different agar media after which E. coli colonies were allowed to grow out.

Non-treated plants (80 in total) at day 45 were inoculated with each of the three E. coli strains and water (as control) in the flower receptacle, or in the first leaf axil below the developing flower receptacle ( $n=5$, three strains plus control and two inoculation types leading to eight treatments) in separate plants to investigate whether local inoculation with E. coli could lead to (internal) seed infection. Therefore, wounds were created by punching with a sterile needle into the flower receptacle and leaf axil tissues, and five $\mu \mathrm{L}$ droplets, containing no (control) or between Log 6.4 and 6.6 E. coli CFUs, were placed on top of these wounds. Two hours after applications, the droplets were taken up by the plants and five and $35 \mathrm{~d}$ after inoculation, at 50 and 80 DAS respectively, treated plants were analysed for the local presence of E. coli at the inoculation sites and/or in developing pods and seeds. At 50 DAS, only developing pods were analysed for plants inoculated at flower receptacles, whereas for plants inoculated at the leaf axils, developing pods, leaf axil and internode tissue were sampled. At 80 DAS, developed pods and seeds were sampled for both treatments. Samples taken from all tissues, of between 0.3 and $2 \mathrm{~g}$ in weight, were further processed and plated on agar media for E. coli colony formation. Ripened seeds from plants of all 16 treatments, taken at 80 DAS (one seed per plant; $n=5$ per treatment) were collected and stored at $4{ }^{\circ} \mathrm{C}$ for later analysis on presence of $E$. coli.

\subsection{Colonization of Pea Plants by Strain 55989, Introduced onto Seeds, under Open Field Circumstances}

Field studies in two consecutive years were conducted with pea plants grown from water (control) and strain 55989-treated seeds in the periods between 28 May and 20 August 2015 and between 26 May and 17 August 2016. Both studies were performed in an agricultural field at the Unifarm experimental farm of Wageningen University and Research centre (GPS coordinates, $51^{\circ} 59^{\prime} 18.0^{\prime \prime} \mathrm{N} ; 5^{\circ} 39^{\prime} 40.1^{\prime \prime} \mathrm{E}$ ). The field was $4 \mathrm{~m} \times 6 \mathrm{~m}$ in size and was covered by a net to avoid entrance of birds into the field. The soil at the Unifarm field location was a sandy soil consisting of $86 \%$ sand, $9 \%$ silt, $1 \%$ clay, organic matter content of $3.9 \%$ and $\mathrm{pH}$ of 5.9. In the first field experiment, one seed treatment was applied; i.e., seeds submerged in strain 55989 solution. Seeds submerged in water served as control and for each sampling, five plants per treatment and sample time were used. Plants were sampled for analysis in the presence of strain 55989 in rhizosphere soil, roots, stem base and seeds. For the second field experiment, five seed treatments were applied that are realistic under commercial seed treatment and storage circumstances: (1) submergence, (2) drop inoculation, (3) drop inoculation followed by $48 \mathrm{~h}$ storage at $96 \% \mathrm{RAH},(4)$ same as 3, but then stored at 36\% RAH, and (5) submerged and stored for $35 \mathrm{~d}$ at $4{ }^{\circ} \mathrm{C}$. Seeds submerged in water were used as control, leading to six treatments using five plants per 
treatment and sampling time. At 0 DAS (28 May 2016) seeds were sown into the soil and at 28, 49, 62 and 83 DAS, plants were sampled and analysed for presence of strain 55989 in rhizosphere soil, roots and seeds. Sampling times were chosen on the basis of the same plant developmental stages as in the first field experiment. At the first, second, third and fourth samplings in 2015 and 2016, plants were, respectively, in the seventh true leaf stage, in the flowering stage, at the end of flowering/beginning of the pod filling stage, and at the senescent stage with ripened seeds. Plant development was slower in the second than in the first year of field experimentation, due to lower temperatures in 2016, and therefore samples were taken at later time points after sowing in 2016 than in 2015. For each sampling, plants with roots were taken from the soil and soil loosely attached to roots was removed by shaking. Intact plants were separately packed in plastic bags and transported to the laboratory where all samples were processed on the same day. Soil firmly attached to roots was considered to be 'rhizosphere soil' and per plant between one and seven $g$ mixed roots with soil were shaken in sterile $50 \mathrm{~mL}$ plastic tubes filled with one g gravel and $20 \mathrm{~mL} 0.1 \%$ sodium pyrophosphate solution. Tubes were vortexed for one min and soil suspensions were either plated non-diluted onto BECSA, or in 10-fold serial dilutions made in $0.1 \%$ sodium pyrophosphate solution. Then, roots were removed from the tubes, two times rinsed in sterile demineralized water and pat dried on sterile filter paper. Stem base parts (only taken in 2015 and between $0.2 \mathrm{~g}$ and maximally $3 \mathrm{~g}$ in weight) and rinsed roots (between 0.5 and $4 \mathrm{~g}$ ) were transferred to Bioreba bags containing three $\mathrm{mL}$ Ringer solution, after which stem base and root parts were hammered and thus derived extracts were plated undiluted and tenfold serial diluted. Individual purple stained colonies, indicative for strain 55989, at the last samplings in 2015 and 2016 (respectively, at 85 and 83 DAS) were streaked to purity onto BECSA and single colonies were grown overnight in $\mathrm{LB}$ at $37^{\circ} \mathrm{C}$. Resulting dense cultures were either mixed with sterile glycerol to a final concentration of $20 \%$ for storage at $-70{ }^{\circ} \mathrm{C}$, or cells from one $\mathrm{mL}$ culture suspensions were pelleted by centrifugation after which DNA was extracted from resulting cell pellets for whole genome sequencing, using the Illumina MiSeq platform. Comparison of obtained isolates with strain 55989 and other E. coli strains, as described in van Overbeek et al. [23], was made on the basis of DNA sequences of 10 cellular household genes, i.e., adenylate kinase ( $a d k)$, classII fumarate hydratase (fum C), glycerol kinase $(g l p \mathrm{~K})$, DNA gyrase subunit B (gyrB), 3-isopropylmalate dehydrogenase (icd), diaminopimelate decarboxylase (lys A), malate/lactate/ureidoglycolate dehydrogenase ( $m d h)$, methionine-tRNA ligase (met $\mathrm{G})$, adeylosuccinate synthetase (purA), and DNA recombination/repair protein (recA).

Seeds, five per treatment (two in field experiment 1 and six in field experiment 2) from different plants taken at the last samplings in both years, were collected and stored at $4{ }^{\circ} \mathrm{C}$ for later analysis for eventual presence of E. coli.

\subsection{Analysis for Presence of E. coli in Surface-Sterilized Seeds}

All collected seeds from greenhouse and both field experiments, coming to a total of 120 seeds, were surface disinfected using $1 \%$ chlorine solution as described before. Final wash water was plated onto the agar medium respective for each E. coli strain, using BECSA for water-treated controls. Disinfected seeds were allowed to germinate on sterile water-soaked filter paper in Petri dishes for $6 \mathrm{~d}$ in the dark at room temperature. Then, emerging plants were transferred to Bioreba bags containing $3 \mathrm{~mL}$ Ringers solution, hammered and resulting extracts were directly plated onto the agar medium respective for each strain, using BECSA for extracts from plantlets grown from water-treated seeds (control extracts). In parallel, these control extracts were also spiked with strain 55989 (to an estimated final density of Log 4 CFU per $\mathrm{mL}$ ) and plated onto BECSA as a control for the establishment of eventual $E$. coli growth inhibition in pea seed extracts.

\subsection{Data Processing and Statistics}

E. coli densities on seeds, in root, pod or stem tissue, and in rhizosphere soil were expressed as $\log _{10}(n+1)$ values per seed, per g of plant or per g of dry soil, respectively. Prevalence was defined as the number of samples with detectable (introduced) E. coli CFUs. When absent in a sample, introduced E. coli was considered to be undetectable and the lowest limit of detection was calculated 
on the basis of lower than one single colony on duplicate plates that had received non-diluted extracts. These numbers are expressed as ' 0 ' values. Geometric means were calculated from Log-converted values and used for statistical analysis of variance (ANOVA, Genstat 19th Ed. Hemel Hempstead, UK). Differences were considered to be different at levels of $p=0.05$ and below.

\section{Results}

\subsection{Attachment of E. coli Strain 55989 Cells to Pea Seeds}

Strain 55989 cells attached to pea seeds within one min upon exposure. Of the Log 5.59 CFUs per seed used for exposure, on average Log 2.52 CFUs firmly attached to the seeds, even after two washes with Ringer solution, which is a fraction of $0.09 \%$ of the total inoculum added to seeds (Figure S1). Elongation of the exposure time to five, 10, 30 and $60 \mathrm{~min}$ resulted in higher average values of, respectively, $\log 2.66,3.69,3.29$ and 3.63 CFU per seed, and the average cell number attached after one minute on seeds was significantly lower than after 10 and $60 \mathrm{~min}$, but not after five and $30 \mathrm{~min}$. The highest fraction (1.2\% of the inoculum) of strain 55989 cells attaching to pea seeds was observed at $10 \mathrm{~min}$ and after that time the fraction of attaching cells remained about stable. A linear relationship existed between the density of cells applied to seeds for $60 \mathrm{~min}$ and the ones still attaching to seeds after two washes (Figure 1). Based on these data, it was decided to choose for the highest possible inoculum densities, by making use of late exponential E. coli cell cultures consisting of Log 9 CFU per $\mathrm{mL}$ and over, upon a standard exposure time of $60 \mathrm{~min}$. Two seed inoculation procedures were applied throughout this study, i.e., seed submergence and spot inoculation and the main differences between the two inoculation types are that spot inoculation resulted in a local contamination on the seed surface, which may better reflect contaminations occurring under practical circumstances, and that the inoculum dose was about Log 1.2 CFU per seed lower for spot than for submergence inoculation. Strain 55989 cells, attached to pea seeds, were still sensitive to three different disinfection reagents (Figure S2). This indicates that the strain 55989 cells attached to seeds were accessible for these reagents. Strain 55989 cells on dried pea seeds persisted for $35 \mathrm{~d}$ at $4{ }^{\circ} \mathrm{C}$ (a temperature realistic for seed storage in practice) on the seed surface at about the same level (on average Log 6.83 CFU per seed) as at the moment of introduction onto the seeds (Log 6.56 CFU per seed). Also, strain 55989 cells attached to seeds could persist with low air humidity ( $36 \% \mathrm{RAH})$ for $48 \mathrm{~h}$. When compared to inoculated seeds stored for the same time period at 96\% RAH, the number of strain 55989 cells on seeds was slightly (Log 0.3 CFU per seed), but not significantly lower. In conclusion, application of strain 55989 cells on pea seeds resulted in a robust and persistent contamination of the seed surface.

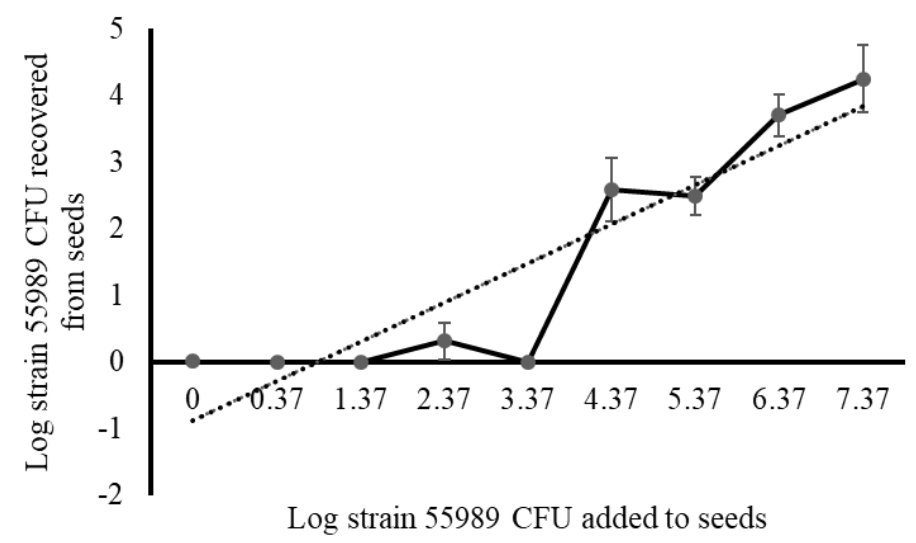

Figure 1. Relationship between the density of E. coli strain 55989 cells exposed to pea seeds and number of cells attaching to the seed surface. Seeds were exposed to different strain 55989 cell densities for $60 \mathrm{~min}$, where after treated seeds were two times washed prior to analysis for presence of strain 55989 cells that remained attached to the seed surface. Dashed line represents the linear regression line $\left(y=0.6219 x-0.6588 ; R^{2}=0.7961\right)$. 


\subsection{Colonization of Pea Plants Emerging from Seeds by Three E. coli Strains}

Log CFU numbers per seed at the time of sowing (0 DAS) were 8.66, 8.64 and 8.47 on seeds submerged in suspensions of, respectively, strains 55989, 0611 and N112, whereas upon drop inoculation numbers were, respectively, 7.34, 7.31 and 7.39. Eight days after sowing, E. coli CFUs were recovered from the cotyledon although numbers were between Log 0.43 and 3.38 per seed lower than at 0 DAS (expressed in $\triangle$ CFU values, see Figure 2). Overall, E. coli CFUs per cotyledon from the seed submergence treatments (6.22) were higher than from the drop inoculation treatments (3.22), whereas no significant differences were observed between the different strains within each seed inoculation method. Primary roots at 8 DAS were already colonized by the three strains, irrespective of the applied inoculation method, although on average higher $E$. coli Log CFU numbers per g plant were on roots developed from 'submerged' seeds (4.55) than on the ones developed from 'drop inoculated' seeds (3.14) (Figure 3). No significant differences on primary roots were observed between strains for each seed treatment method. Over time, from 19, 34 and 62 DAS, both E. coli prevalence (i.e., E. coli was present at a detectable level in the sample) and cell density levels (expressed in geometric averages over the five samples) on primary and secondary roots equally declined for all three E. coli strains. Overall, prevalence and Log CFU numbers per g root were higher for plants grown from 'submerged' than from 'drop inoculated' seeds, but still at 62 DAS, colonies from all three strains were recoverable from roots from both seed inoculation methods. This in contrast to E. coli CFUs from epicotyls at 8 DAS, where Log CFU numbers per g plant were between 0 (undetectable) and 5.06 (Figure 3). There were clear distinctions in E. coli prevalence and cell density levels in epicotyls between plants grown from 'submerged' and from 'drop inoculated' seeds; i.e., E. coli was found in 10 of 15 plants at an average density of Log 1.94 CFU per g plant in epicotyls developed from submerged seeds, whereas in 2 of 15 plants at average density of Log 0.56 CFU per g plant in epicotyls developed from 'drop inoculated' seeds. Over time from 19 to 62 DAS, E. coli prevalence and cell density numbers in stem base samples declined, although CFUs from all three strains were recoverable in stem base samples taken at 62 DAS from plants grown from the submerged seeds only. Over the same time period, no E. coli CFUs were found in the top stem samples indicating that none of the applied E. coli strains systemically spread to higher located places in the pea stems. Therefore, it is unlikely that it can be assumed that $E$. coli cells applied to seeds would lead to systemic spread throughout the entire plant finally resulting in invasion of plant reproductive organs. Therefore, it was investigated whether local introductions of E. coli strains at the start of flower development could lead to (internal) seed contamination.

Introduction of $E$. coli cells to receptacles of developing flowers and to the first leaf axil below developing flowers in untreated plants at 45 DAS led to consistent high recovery of CFUs of all three E. coli strains at the inoculation sites at 50 DAS (Figure 4). However, further systemic spread from the leaf axil to internode tissue at 50 DAS was limited as E. coli prevalence (between 1-3 out of 5 replicate plants per strain) and density levels (between Log 0 and 3.90 CFU per g plant) were low. Thirty five days after flower receptacle treatment, E. coli CFUs for all three strains were almost consistently found in pods at between Log 0 (one plant treated with strain N112) and 6.44 CFU per g plant. However, no E. coli CFUs were found in pods from plants inoculated at the leaf axils. Furthermore, no E. coli CFUs were found in water, collected from all treatments (strain $x$ seed inoculation method), after the last washing after seed disinfection and in plantlets emerging from disinfected seeds, indicating that no internal seed contamination had taken place. However, in control samples that were spiked with strain 55989 cells, E. coli CFUs were found on plates upon incubation, demonstrating that the absence in $E$. coli colony formation was not the result of $E$. coli growth inhibition by compounds present in plant extracts. Therefore, it must be concluded that local plant contamination, even to most proximate places of the plant reproductive organs, did not lead to internal seed infection by any of the three investigated E. coli strains. 


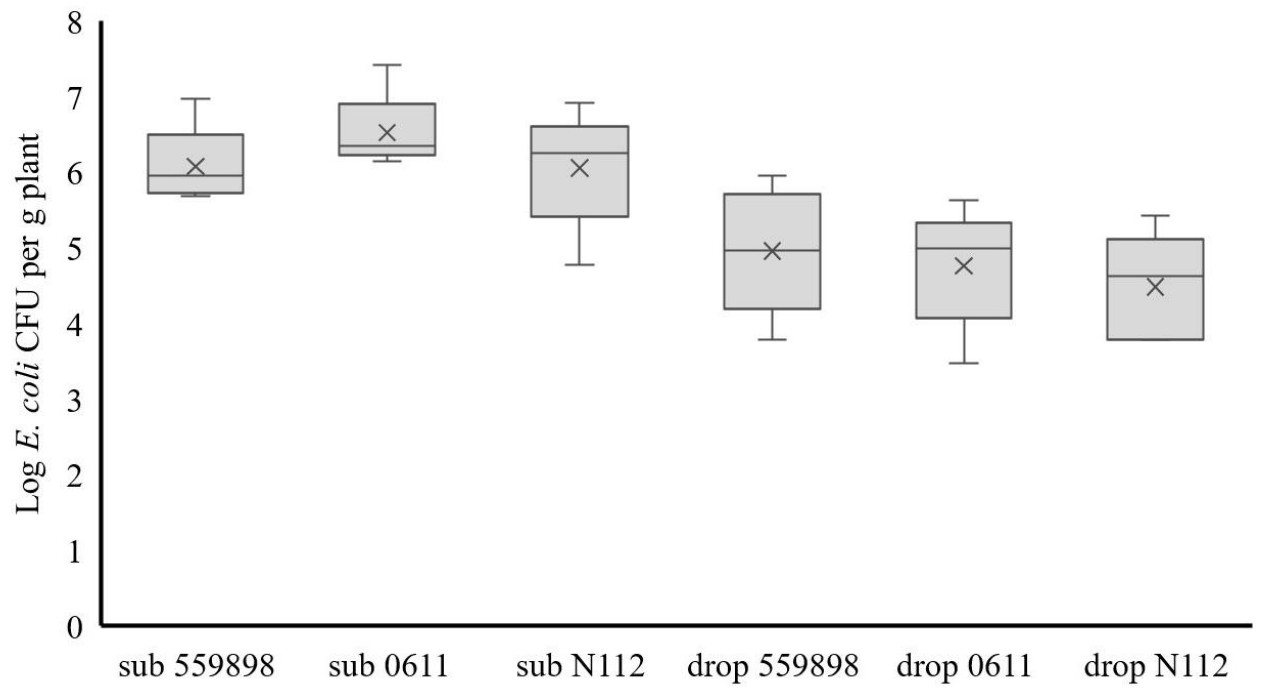

B

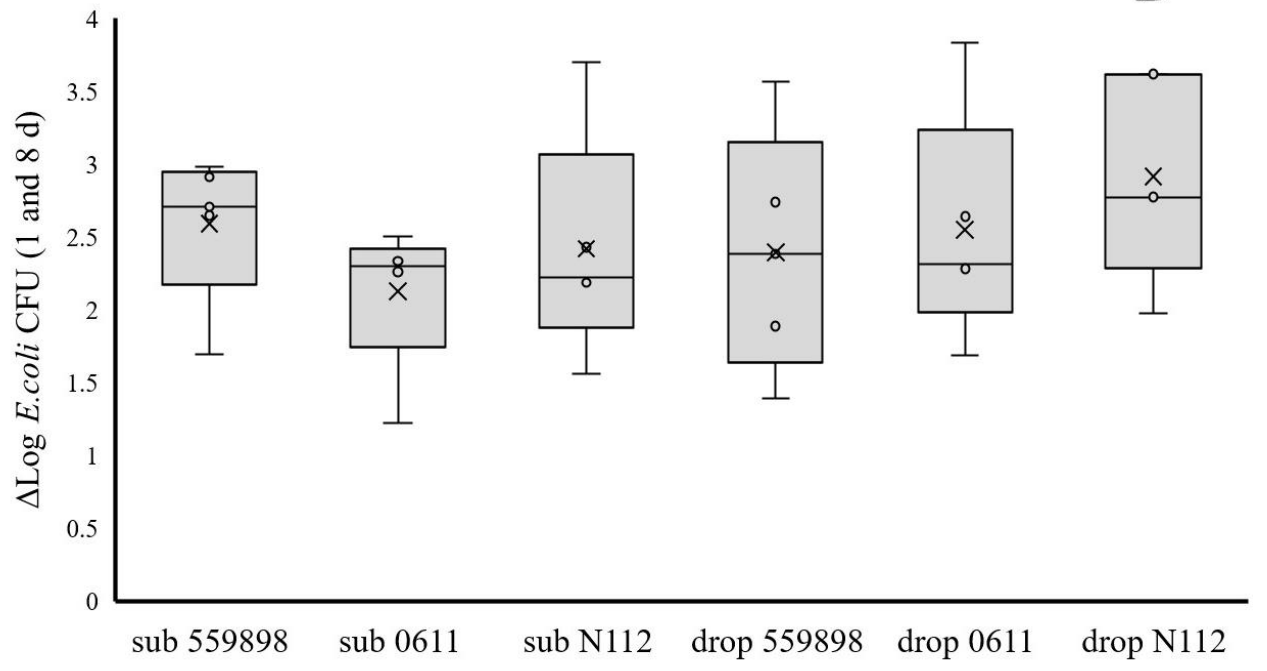

Figure 2. Persistence of three E. coli strains on pea cotyledons after 8 DAS (A) and the difference between E. coli colony forming units (CFUs) at 0 DAS on seeds and at eight DAS at the cotyledons, expressed as $\Delta \log E$. coli CFU values (B). Cells of three E. coli strains $(55989,0611, N 112)$ were administered to seeds via submergence (sub) or inoculation by placement of $10 \mu$ droplets on the seed surface (drop).

3.3. Colonization of Pea Plants by E. coli Grown from Seeds Treated with Strain 55989 Cells under Open Field Circumstances

Experiments over two successive years were conducted with pea seeds treated with strain 55989 and (water-treated) control seeds in the open field in soil under fluctuating temperature, water and air humidity regimes, in the omission of any treatment for plant pest and disease control. Under these circumstances, pea plant development was comparable as under greenhouse circumstances, although plants were between 10-15 cm smaller in the open field than in the greenhouse. In the first field experiment, performed in 2015, seeds were treated with strain 55989 cells by submergence, resulting in a load of Log 8.79 CFU per seed at 0 DAS. In control plants, strain 55989 CFUs were never found at any time point during the experiment in root, stem, rhizosphere soil and seed samples. After 18 DAS, strain 55989 CFUs were recovered from roots from 4 out of 5 plants grown from strain 55989 seeds at an 
average density of Log 2.33 CFU per g plant (Figure 5). Later at plant growth, strain 55989 prevalence and densities in roots declined, and only one sample (of 8) was found positive for strain 55989 at 85 DAS, when plants were at a senescent stage. Only one stem sample (of five) was found to be positive for strain 55989 at 18 DAS, at a level of Log 1.54 per g plant, in a plant grown from a strain 55989-treated seed. No strain 55989 CFUs were recovered from stem samples at later plant growth stages. This to the contrary to rhizosphere soil, where strain 55989 CFUs were more consistently present. At 18 DAS, strain 55989 density level was on average Log 3.14 CFU per g dry soil, but this density declined at later plant growth stages and at 85 DAS one, of eight, investigated plants was found positive for strain 55989. Strain 55989 thus had a stronger preference for colonization of the root zone than for the above-ground plant compartments. Genomic DNA of two purified isolates taken from roots and rhizosphere soil at 85 DAS revealed that both isolates were identical to strain 55989 on the basis of 10 E. coli household genes. However, one other isolate from rhizosphere soil sampled at 85 DAS, with a colony morphology slightly deviating from strain 55989, was genotypically not identical to strain 55989, but clustered with other E. coli strains in the same phylogenetic tree. The presence of strain 55989 in roots and rhizosphere soil of senescent pea plants was therefore confirmed, although also another E. coli strain was present in rhizosphere soil that was not applied in the seed treatment. No E. coli CFUs were found in plantlets emerged from ripened (dry) and surface disinfected seeds collected from strain 55989 plants.

The second field experiment, conducted in 2016, was focused on root zone and seed colonization by strain 55989 only, using five different strain 55989 and one control treatments. Seed loads with strain 55989 at 0 DAS were (in Log CFU per seed): 8.24, 7.36, 8.36, 8.04 and 6.83, respectively, for the following seed treatments: (1) submerged, (2) drop inoculated, (3) submerged and $48 \mathrm{~h}$ stored at 96\% RAH, (4) submerged and $48 \mathrm{~h}$ stored at $36 \% \mathrm{RAH}$ and (5) submerged and stored for $35 \mathrm{~d}$ at $4{ }^{\circ} \mathrm{C}$. Over all sampling points, no strain 55989 CFUs were found in rhizosphere soil, roots and seeds of control plants. In roots sampled at 28 DAS, highest prevalence was found in plants grown from drop-inoculated seeds and seeds stored for $48 \mathrm{~h}$ at 96\% RAH (presence of strain 55989 in all five plants for both treatments; Figure 6). For the other three treatments at 28 DAS, strain 55989 was present in only one or two of the five analyzed samples (Figure 6). Prevalence (between zero and four) and density values (between Log 0 and 2.02 strain 55989 CFU per g plant) dropped over time in roots at 49 and 62 DAS and at 83 DAS only one sample was found positive at a density level of Log strain 2.51 strain 55989 CFU per g plant (seed treatment at 36\% RAH for $48 \mathrm{~h}$ ). Similar to the first field experiment, strain 55989 was also found present in rhizosphere soil. At 28 DAS, strain 55989 CFUs were found in almost all rhizosphere soil samples, with the exception of one from plants grown from a seed stored for $35 \mathrm{~d}$ at $4{ }^{\circ} \mathrm{C}$ (Figure 6). Density levels in rhizosphere soil at 28 DAS were significantly higher when plants were grown from submerged seeds and seeds stored for $48 \mathrm{~h}$ at 96\% RAH (at respectively Log 2.30 and 2.51 strain 55989 CFU per $g$ dry soil) than in the ones grown from seeds that were stored for $35 \mathrm{~d}$ at $4{ }^{\circ} \mathrm{C}$, or stored for $48 \mathrm{~h}$ at $36 \% \mathrm{RAH}$, or that were drop inoculated (respectively, at levels of Log 1.42, 1.67 and 1.98 CFU per $g$ dry soil). Over time, prevalence of strain 55989 dropped, occasionally to below three positive samples per treatment. However, the high prevalence at 62 DAS in roots of plants grown from the seeds stored for $48 \mathrm{~h}$ at $36 \%$ and at $96 \%$ RAH (respectively, five and four of five tested samples were found positive for strain 55989), indicated that dry storage of contaminated seeds does not affect plant colonization by E. coli strain 55989. At 83 DAS, prevalence was lowest of all sampling points and strain 55989 CFUs were only recovered from two samples; one from plants grown from drop-inoculated seeds, and the other from seeds stored at 36\% RAH for $48 \mathrm{~h}$. Of the seven isolates from rhizosphere soil (two) and roots (five) at 83 DAS, four (two from rhizosphere soil and two from roots) were identical to strain 55989 on the basis of gene sequences of $10 \mathrm{E}$. coli cellular household genes. The other three isolates (all from roots) were different from strain 55989, but still were identified as E. coli. Plantlets emerged from collected and surface-sterilized seeds from all treatments and taken at last samplings at 83 DAS (five seeds from different plants per treatment, six treatments, 30 seeds in total) in the second field experiments were all negative, confirming the observation made in the greenhouse experiment 
and the first field experiment that transmission of strain 55989 cells via the mother plant to internal compartments of the next generation of seeds must be considered as an unlikely event.

A

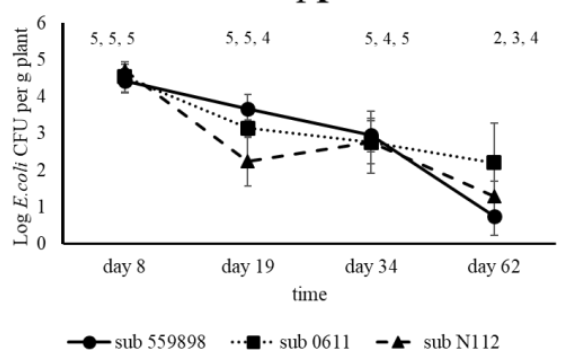

C

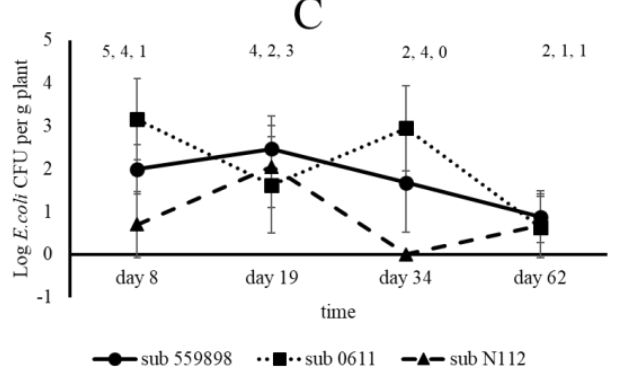

B

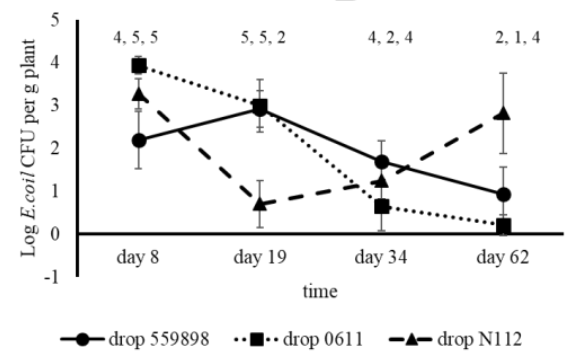

$\mathrm{D}$

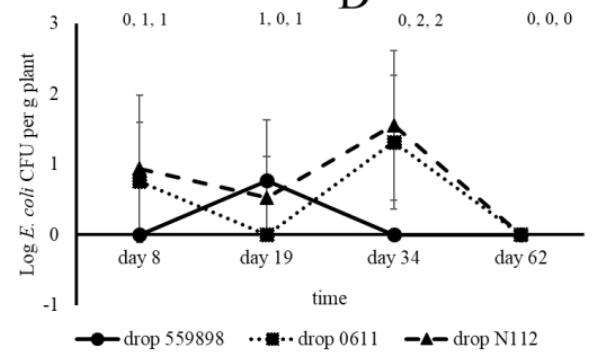

Figure 3. Colonization of roots $(\mathbf{A}, \mathbf{B})$ and epicotyl/stem base $(\mathbf{C}, \mathbf{D})$ of pea plants grown from seeds treated with E. coli strains 55989, 0611, or N112, either via seed submergence $(\mathbf{A}, \mathbf{C})$ or drop inoculation (B,D). Symbols: circle, strain 55989; square, strain 0611; triangle, strain N112. Numbers above symbols indicate the number of plants found to be positive for the presence of introduced E. coli strains, of five replicate plants.
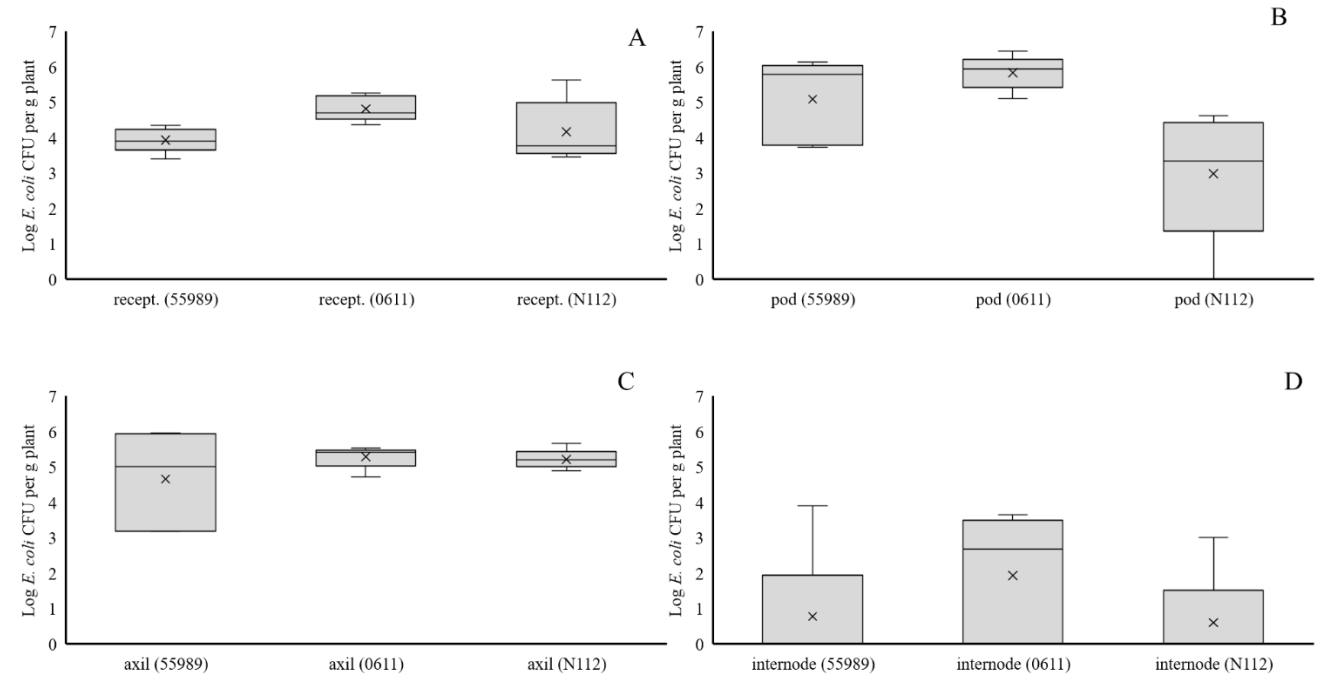

Figure 4. Colonization of flower receptacles at 50 DAS (A), pea pods at 80 DAS (B), leaf axils at 50 DAS (C) and first internode above the leaf axil at 50 DAS (D), upon injection of three E. coli strains (55989, 0611, or N112) into, respectively, flower receptacles (A,B) or leaf axils (C,D) at 45 DAS. 


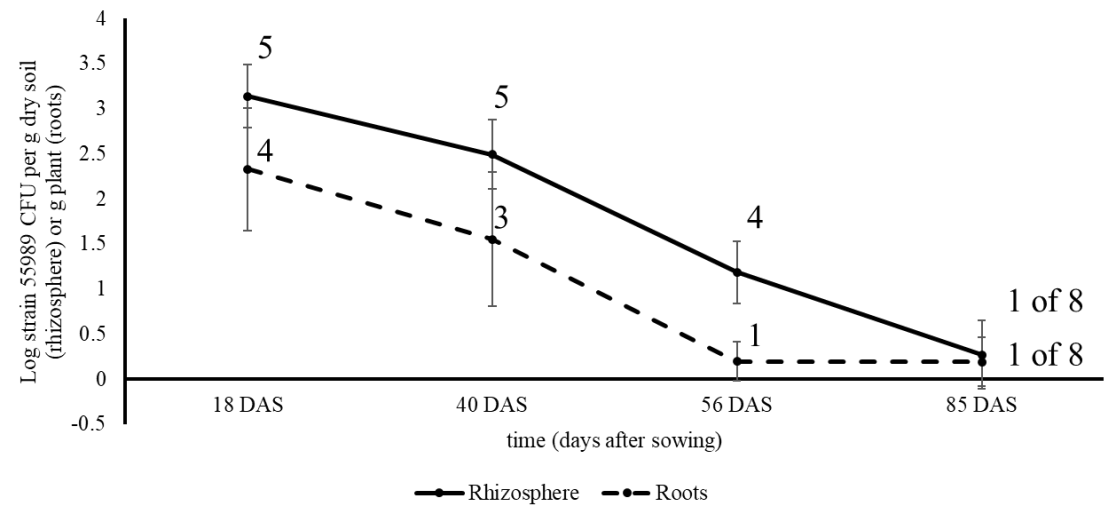

Figure 5. Colonization of roots and rhizosphere soil of pea plants by strain 55989, emerged from seeds treated with strain 55989 cells, under open field circumstances in 2015. Solid line, rhizosphere soil; dashed line, roots; numbers above symbols indicate the number of plants found positive for presence of strain 55989, of five replicate plants taken at 18, 40 and 56 DAS and of eight at 85 DAS.

A

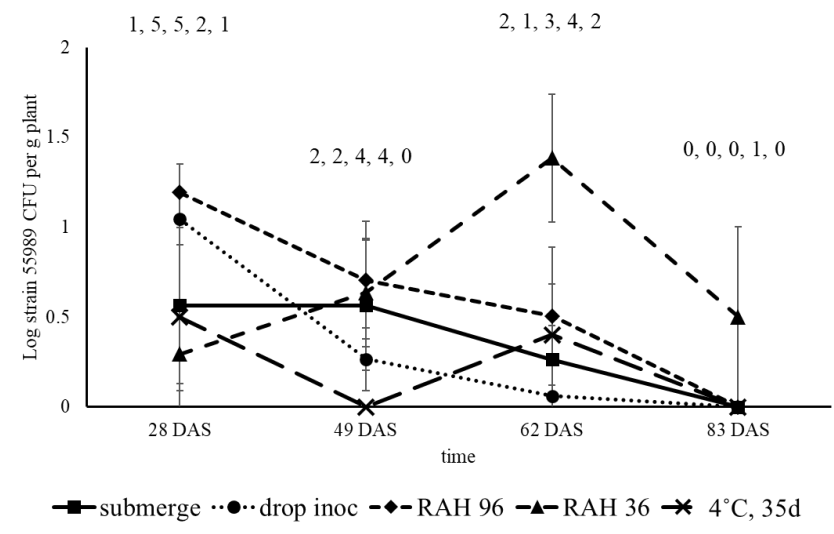

B

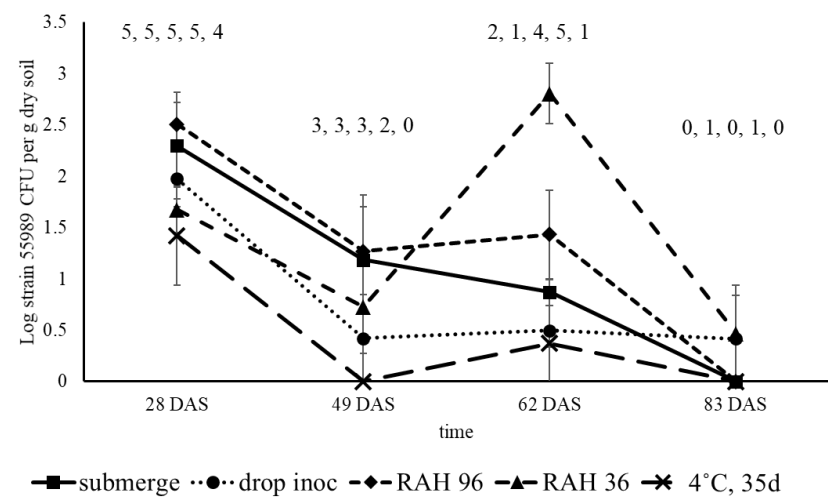

Figure 6. Colonization of roots (A) and rhizosphere soil (B) of pea plants by strain 55989, emerged from strain 55989-inoculated seeds, treated under different bacterial seed application and storage regimes, under open field circumstances in 2016. Square, seed submergence; circle, drop inoculation; diamond, seed submergence, followed by storage at $96 \%$ relative air humidity (RAH) for $48 \mathrm{~h}$; triangle, seed submergence, followed by storage at $36 \% \mathrm{RAH}$ for $48 \mathrm{~h}$; cross, seed submergence followed by seed storage at $4{ }^{\circ} \mathrm{C}$ for $35 \mathrm{~d}$. Numbers above symbols indicate the number of plants found positive for presence of strain 55989, of five replicate plants at all samplings. 


\section{Discussion}

Entero-aggregative E. coli strain 55989 was able to colonize the root compartment of pea plants from inoculated seeds. In the root and rhizosphere soil, the strain could persist until the senescent stage of plant growth, when seeds had ripened. Colonization of the above-soil parts of the plants by strain 55989 was negligible and, therefore, translocation of strain 55989 cells via the vascular tissue of the stems to developing seeds seems unlikely. The fact that even proximate introductions of cells of all three strains to developing flowers did not result in effective internal seed contamination led to the conclusion that there is no evidence for internal transmission of E. coli via plants to developing seeds. The consequence thereof is that E. coli O104:H4 will not be transmitted as internal seed contaminant to next generations of plants, at least not in pea plants. However, as external seed contaminant, E. coli O104:H4 will be transmitted to next generations of plants and its ecological behaviour in plants is the same as for the two other E. coli strains. This is an important aspect because it demonstrates that pathogenic E. coli strains can contaminate crop production sites by making use of seeds as primary vectors for transmission to growing plants. The soil environment plays an important role in further transmission of these pathogens to edible parts of the plants. Our finding corroborate that of Habteselassie et al., [14], where it was demonstrated that the rhizosphere played an important role in the early establishment and colonization of radish and lettuce plants by E. coli O157:H7.

The two E. coli phylotype B1 strains used in our study (O104:H4 strain 55989 and O150:H2 strain N112) were indistinguishable in their ecological behaviour in, and near developing pea plants, this in spite of their differences in pathotype. The behaviour of the two phylotype B1 strains on their turn were indistinguishable from the third one, the ESBL-producing E. coli strain 0611 that originated from plants. Niche partition and adaptation to natural habitats has been hold responsible for diversification of different $E$. coli clades in their ecological behaviour in many natural habitats such as in soils $[18,19,22,36]$, but most likely this does not hold true for plant ecosystems. In plants and their surrounding areas (rhizosphere soil), plant-released nutrients are available for cell proliferation and like many bacteria naturally occurring in soils, E. coli profit from available nutrients explaining the long-term persistence near pea roots and in rhizosphere soils as demonstrated in both field experiments. The three E. coli strains declined over time in the pea rhizosphere which contrasted the ecological behaviour of the typical soil-borne bacterial species Pseudomonas fluorescens that persisted at constant and higher levels in the pea rhizosphere [37]. Although not a species fully adapted to soil environments, E. coli responded here in an opportunistic fashion to nutrients made available by plants, either at seed emergence or at root exudation. The fact that E. coli isolates were found in pea rhizosphere soil and roots that differed from the introduced strain 55989 indicate that E. coli is intrinsically present in pea plants or their proximate surroundings. Therefore, these strains must be considered as indigenous inhabitants of the pea plant microbiome. This would also indicate that these E. coli strains are adapted to life near or even inside plants. The presence of E. coli in plants is still an unknown fact and would require further attention in eventual later studies. Altogether, this emphasizes the fact that plants must be considered as alternative ecosystems for E. coli [26].

The above soil compartments of the pea plants were less colonized than the roots by all three E. coli strains, indicating that these parts of the plants are less favoured for colonization by E. coli in general. Most likely nutrient availability was limited at the epicotyl from where later at plant growth the stem base developed. Possibly a part of the E. coli populations colonized the internal tissue of the stem base, but because no surface sterilization attempts were undertaken in our study, no information can be provided on exact numbers of $E$. coli cells internalized into plants. Internalization of spinach, lettuce and Nicotiana benthamiana by E. coli O157:H7 was reported in Wright et al. [9] and internalization was indicated to play a critical role with respect to food safety and human health [8]. However, food safety was not the principal motive for our research, but instead it was the ecological behaviour in, or on plants, in relation to colonization of developing seeds. From our study we can conclude that either via external, or internal colonization, even upon introduction shortly before flower formation, no internal seed colonization by any of the three studied E. coli strains took place. From 
there, it can be concluded that E. coli, under realistic growth circumstances, is not able to cross the barrier between maternal and embryonic tissue in pea plants. This in contrast to a typical endophyte, Paraburkholderia phytofirmans PsJN, that was able to colonize internal seed compartments of maize, soy and pepper upon flower spraying [32]. Most likely, E. coli lack the appropriate cellular equipment to independently penetrate plant tissue like endophytes do. Penetration of $E$. coli into seeds can be forced, e.g., by vacuum infiltration [38], but these are circumstances that do not occur under realistic plant growth circumstances.

From seeds, E. coli and S. enterica strains were shown to colonize cotyledon and the primary roots of emerging alfalfa, fenugreek, lettuce and tomato plants [38], in a fashion comparable to what was shown in our study with the three E. coli strains in pea plants. In the study done by Liu and co-workers [38], the pathogens were present under the seed coat, whereas in our study, the E. coli strains were applied on the seed coat. It seems that no difference exist in colonization of plants either by E. coli pathogens present inside or on the surface of seeds. In our study, the time needed for attachment to pea seeds was within one minute upon exposure and no differences in efficiency of attachment to the pea seed surface was observed between the three strains. In Cui et al. [2], it was reported that differences in seed attachment between E. coli O157:H7 and O104:H4 was present on different seed types (alfalfa, fenugreek, lettuce and tomato). Escherichia coli O104:H4 strain ATCC BAA2326 (Hamburg 2011 outbreak strain) showed the lowest attachment potential in comparison with three E. coli O157:H7 strains. Lowest attachment may be related to relative higher EPS production by E. coli O104:H4 strains, favouring biofilm formation, but restricting adherence to solid surfaces [2]. Also, higher cell hydrophobicity and rougher (more wrinkled) seed surface type often result in higher attachment of bacterial pathogens to seeds [2]. So, in spite of the facts that: (i) E. coli has a relatively lower surface hydrophobicity, (ii) E. coli O104:H4 is less efficient in attachment to solid surfaces, and (iii) that the surface of pea seeds is rather smooth, we still observed long-term persistence to up to 35 days of E. coli strain 55989 on the pea seed surface, and this strain was also shown to stay alive at low RAH of $35 \%$ for $48 \mathrm{~h}$ on the pea seed surface. In line with observations made by van der Linden et al. [3], it must be concluded that $E$. coli can persist over long periods in time on seed surfaces and these time periods and storage conditions are realistic in commercial seed production and logistics circumstances. It can therefore be concluded that presence of $E$. coli on seeds, used for starting materials in fruit and vegetable production, pose a potential risk for food safety unless these seeds are appropriately disinfected.

It was demonstrated before that pea seeds can become contaminated with human pathogens as demonstrated at the Campylobacter jejuni outbreak in Alaska in 2008 [39]. In case human pathogens are present on seeds used as starting materials for cultivation of crop plants, then a risk on contamination of the edible parts of the plants may exist. From contaminated seeds, human pathogens can reach rhizosphere soil from where they can contaminate edible parts grown below the soil surface, as will be the case for radish and carrot plants, or the edible parts shortly above the soil surface, as will be the case for leafy greens. With regard to the consequences on long-term persistence of pathogenic E. coli strains in soils of plant production systems, nothing is certain at the moment. Phytopathogens may create ports of entrances for human pathogens from where these pathogens further spread to the edible parts. However, no internalization occurred in spinach plants by E. coli O157:H7 when two pathogens, Pseudomonas syringae and Meloidogyne hapla, were present in the production site [17], indicating that plant pathogens do not play a dominant role in contamination of plants by human pathogenic E. coli. However, gene fluxes in E. coli are high $[18,36]$ and auxiliary genomes of E. coli are often prone to homologous recombination [20]. Adaptation of pathogenic E. coli strains to the plant environment might result from gene acquisition events taking place in plants and their surrounding areas $[18,31]$. On the longer run this may result in selection of new types of pathogenic E. coli strains with improved capacities to colonize plants [21,31]. Therefore, longer persistence of human pathogens in plant environments might become a concern for fresh food production.

In summary, no evidence was provided on seed internalization via growing plants by the entero-aggregative E. coli strain 55989 and the other two tested E. coli strains. Internalization of $E$. 
coli into seeds, followed by transmission to next generations of crop plants, must be regarded as an unlikely event under realistic plant growth circumstances. However, E. coli strain 55989 could persist on the pea seed surface and was shown to survive under commercially applied seed storage conditions. All three E. coli strains showed stronger preference for the root-soil zones of growing pea plants than for the above soil plant compartments, in spite of their differences in clinical behaviour and origin. Therefore, these observations can be expanded to broader groups of (pathogenic) E. coli strains with the concept that contaminating E. coli strains will colonize root compartments of crop plants in production systems and from there are able to further spread to consumable parts of plants. Adequate seed disinfection protocols should avoid contamination of arable soils used for cultivation of freshly consumable crop plants.

Supplementary Materials: The following are available online at http://www.mdpi.com/2076-2607/8/9/1271/s1; Figure S1: Recovery of strain 55989 CFUs from washed pea seeds (A) and from the first (B) and second (C) wash solutions. Figure S2: Effect of disinfection solutions on persistence of strain 55989 on pea seeds.

Author Contributions: Conceptualization, L.S.v.O.; investigation, C.L.-v.d.P. and P.v.d.Z.; formal analysis, L.S.v.O. and P.v.d.Z.; writing, L.S.v.O. All authors have read and agreed to the published version of the manuscript.

Funding: This work was carried out in the public-private collaborative project 'Prevention of contamination of plants with human pathogenic bacteria at primary production' (KV1406 105), granted by the TopSector Horticulture and Starting materials scientific program. Publication of the manuscript was supported by EU COST Action HUPLANTcontrol (16110).

Acknowledgments: We wish to thank Carin van Tongeren for practical assistance in greenhouse and field experiments and Marjon Krijger for E. coli genome comparison in CLC. We thank Cees Veldman from Wageningen Livestock Research for supplying us strain 0611. We thank Edwin Koning, Koppert Cress B.V., Monster, the Netherlands and Victor Sanchez Sava, Incotec Europe B.V., the Netherlands for helpful discussions about seed technology.

Conflicts of Interest: The authors declare no conflict of interest.

\section{References}

1. EFSA Panel on Biological Hazards (BIOHAZ). Scientific Opinion on the risk posed by Shiga toxinproducing Escherichia coli (STEC) and other pathogenic bacteria in seeds and sprouted seeds. EFSA J. 2011, 9, 2424. [CrossRef]

2. Cui, Y.; Walcott, R.; Chen, J. Differential attachment of Salmonella enterica and enterohemorrhagic Escherichia coli to alfalfa, fenugreek, lettuce, and tomato seeds. Appl. Environ. Microbiol. 2017, 83, e03170-16. [CrossRef] [PubMed]

3. Van der Linden, I.; Cottyn, B.; Uyttendaele, M.; Vlaemynck, G.; Maes, M. Long-term survival of Escherichia coli O157:H7 and Salmonella enterica on butterhead lettuce seeds, and their subsequent survival and growth on the seedlings. Int. J. Food Microbiol. 2013, 161, 214-219. [CrossRef]

4. Beutin, L.; Martin, A. Outbreak of Shiga toxin-producing Escherichia coli (STEC) O104:H4 infection in Germany causes a paradigm shift with regard to human pathogenicity of STEC strains. J. Food Prot. 2012, 75, 408-418. [CrossRef] [PubMed]

5. Mellmann, A.; Harmsen, D.; Cummings, C.; Zentz, E.B.; Leopold, S.R.; Rico, A. Prospective genomic characterization of the German Enterohemorrhagic Escherichia coli O104:H4 outbreak by rapid next generation sequencing technology. PLoS ONE 2011, 6, e22751. [CrossRef] [PubMed]

6. Soon, J.M.; Seaman, P.; Baines, R.N. Escherichia coli O104:H4 outbreak from sprouted seeds. Int. J. Hyg. Environ. Health 2013, 216, 346-354. [CrossRef]

7. Ávila-Quezada, G.; Sánchez, E.; Gardea-Béjar, A.A.; Acedo-Félix, E. Salmonella spp. and Escherichia coli: Survival and growth in plant tissue. N. Z. J. Crop Hortic. Sci. 2010, 38, 47-55. [CrossRef]

8. Deering, A.J.; Mauer, L.J.; Pruitt, R.E. Internalization of E. coli O157:H7 and Salmonella spp. in plants: A review. Food Res. Int. 2012, 45, 567-575. [CrossRef]

9. Wright, K.M.; Crozier, L.; Marshall, J; Merget, B.; Holmes, A.; Holden, N.J. Differences in internalization and growth of Escherichia coli O157:H7 within the apoplast of edible plants, spinach and lettuce, compared with the model species. Nicotiana Benthamiana Microb. Biotechnol. 2016, 10, 555-569. [CrossRef] 
10. De los Angeles Dublan, M.; Ortiz-Marquez, J.C.F.; Lett, L.; Curatti, L. Plant-adapted Escherichia coli show increased lettuce colonizing ability, resistance to oxidative stress and chemotactic response. PLoS ONE 2014, 9, e110416. [CrossRef]

11. Crozier, L.; Hedley, P.E.; Morris, J.; Wagstaff, C.; Andrews, S.C.; Toth, I. Whole-transcriptome analysis of verocytotoxigenic Escherichia coli O157:H7 (Sakai) suggests plant-species-specific metabolic response on exposure to spinach and lettuce extracts. Front. Microbiol. 2016, 7, 1088. [CrossRef] [PubMed]

12. Scott, R.A.; Thilmony, R.; Harden, L.A.; Zhou, Y.; Brandl, M.T. Escherichia coli O157:H7 converts plant-derived choline to glycine betaine for osmoprotection during pre- and post-harvest colonization of injured lettuce leaves. Front. Microbiol. 2017, 8, 2436. [CrossRef] [PubMed]

13. Mark Ibekwe, A.; Grieve, C.; Papiernik, S.; Yang, C.-H. Persistence of Escherichia coli O157:H7 on the rhizosphere and phyllosphere of lettuce. Lett. Appl. Microbiol. 2009, 49, 784-790. [CrossRef] [PubMed]

14. Habteselassie, M.Y.; Bischoff, M.; Applegate, B.; Reuhs, B.; Turca, R.F. Understanding the role of agricultural practices in the potential colonization and contamination by Escherichia coli in the rhizospheres of fresh produce. J. Food Prot. 2010, 73, 2001-2009. [CrossRef] [PubMed]

15. Ongeng, D.; Muyanja, C.; Ryckeboer, J.; Geeraerd, A.H.; Springael, D. Rhizosphere effect on survival of Escherichia coli O157:H7 and Salmonella enterica serovar Typhimurium in manure-amended soil during cabbage (Brassica oleracea) cultivation under tropical field conditions in Sub-Saharan Africa. Int. J. Food Microbiol. 2011, 149, 133-142. [CrossRef]

16. Williams, A.P.; Avery, L.M.; Killham, K.; Jones, D.L. Survival of Escherichia coli O157:H7 in the rhizosphere of maize grown in waste-amended soil. J. Appl. Microbiol. 2007, 102, 319-326. [CrossRef]

17. Hora, R.; Warriner, K.; Shelp, B.J.; Griffiths, M.W. Internalization of Escherichia coli O157:H7 following biological and mechanical disruption of growing spinach plants. J. Food Prot. 2005, 68, 2506-2509. [CrossRef]

18. Van Elsas, J.D.; Semenov, A.V.; Costa, R.; Trevors, J.T. Survival of Escherichia coli in the environment: Fundamental and public health aspects. ISME J. 2011, 5, 173-183. [CrossRef]

19. Luo, C.; Walk, S.T.; Gordon, D.M.; Feldgarden, M.; Tiedje, J.M.; Konstantinidis, K.T. Genome sequencing of environmental Escherichia coli expands understanding of the ecology and speciation of the model bacterial species. Proc. Natl. Acad. Sci. USA 2011, 108, 7200. [CrossRef]

20. Wirth, T.; Falush, D.; Lan, R.; Colles, F.; Mensa, P.; Wieler, L.H. Sex and virulence in Escherichia coli: An evolutionary perspective. Mol. Microbiol. 2006, 60, 1136-1151. [CrossRef]

21. Van Overbeek, L.S.; van Doorn, J.; Wichers, J.; van Amerongen, A.; van Roermund, H.J.W.; Willemsen, P.T.J. The arable ecosystem as battleground for emergence of new pathogens. Front. Microbiol. 2014, 5, 104. [CrossRef] [PubMed]

22. NandaKafle, G.; Seale, T.; Flint, T.; Nepal, M.; Venter, S.N.; Brözel, V.S. Distribution of diverse Escherichia coli between cattle and pasture. Microbes Environ. 2017, 32, 226-233. [CrossRef] [PubMed]

23. Van Overbeek, L.S.; Wichers, J.H.; van Amerongen, A.; van Roermund, H.J.W.; van der Zouwen, P.; Willemsen, P.T.J. Circulation of Shiga toxin-producing Escherichia coli phylogenetic group B1 strains between calve stable manure and pasture land with grazing heifers. Front. Microbiol. 2020, 11, 1355. [CrossRef] [PubMed]

24. Wiedemann, A.; Virlogeux-Payant, I.; Chaussé, A.; Schikora, A.; Velge, P. Interaction of Salmonella with animals and plants. Front. Microbiol. 2015, 5, 791. [CrossRef] [PubMed]

25. De Moraes, M.H.; Desai, P.; Porwollik, S.; Canals, R.; Perez, D.R.; Chu, W. Salmonella persistence in tomatoes requires a distinct set of metabolic functions identified by transposon insertion sequencing. Appl. Environ. Microbiol. 2017, 83, e03028-16. [CrossRef]

26. Holden, N.; Pritchard, L.; Toth, I. Colonization outwith the colon: Plants as an alternative environmental reservoir for human pathogenic enterobacteria. FEMS Microbiol. Rev. 2009, 33, 689-703. [CrossRef]

27. Hardoim, P.R.; Hardoim, C.C.P.; van Overbeek, L.S.; van Elsas, J.D. Dynamics of seed-borne rice endophytes on early plant growth stages. PLoS ONE 2012, 7, e30438. [CrossRef]

28. Mendes, R.; Garbeva, P.; Raaijmakers, J.M. The rhizosphere microbiome: Significance of plant beneficial, plant pathogenic, and human pathogenic microorganisms. FEMS Microbiol. Rev. 2013, 37, 634-663. [CrossRef]

29. Hardoim, P.; van Overbeek, L.; Berg, G.; Pirttilä, A.; Compant, S. The hidden world within plants: Ecological and evolutionary considerations for defining functioning of microbial endophytes. Microbiol. Mol. Biol. Rev. 2015, 79, 293-320. [CrossRef] 
30. Köhl, J.; Booij, K.; Kolnaar, R.; Ravensberg, W.J. Ecological arguments to reconsider data requirements regarding the environmental fate of microbial biocontrol agents in the registration procedure of the European Union. BioControl 2019, 64, 469-487. [CrossRef]

31. Kulasekara, B.R.; Jacobs, M.; Zhou, Y.; Wu, Z.; Sims, E.; Saenphimmachak, C.; Miller, S.I. Analysis of the genome of the Escherichia coli O157:H7 2006 spinach-associated outbreak isolate indicates candidate genes that may enhance virulence. Infect. Immun. 2009, 77, 3713. [CrossRef] [PubMed]

32. Mitter, B.; Pfaffenbichler, N.; Flavell, R.; Compant, S.; Antonielli, L.; Petric, A.; Sessitsch, A. A new approach to modify plant microbiomes and traits by introducing beneficial bacteria at flowering into progeny seeds. Front. Microbiol. 2017, 8, 11. [CrossRef] [PubMed]

33. Mossoro, C.; Glaziou, P.; Yassibanda, S.; Lan, N.T.; Bekondi, C. Chronic diarrhea, hemorrhagic colitis, and hemolytic-uremic syndrome associated with HEp-2 adherent Escherichia coli in adults infected with human immunodeficiency virus in Bangui, Central African Republic. J. Clin. Microbiol. 2002, 40, 3086-3088. [CrossRef] [PubMed]

34. Veldman, K.; Kant, A.; Dierikx, C.; van Essen-Zandbergen, A.; Wit, B.; Mevius, D. Enterobacteriaceae resistant to third-generation cephalosporins and quinolones in fresh culinary herbs imported from Southeast Asia. Int. J. Food Microbiol. 2014, 177, 72-77. [CrossRef] [PubMed]

35. Banach, J.L.; van Bokhorst-van de Veen, H.; van Overbeek, L.S.; van der Zouwen, P.S.; van der Fels-Klerx, I. The efficacy of chemical sanitizers on the reduction of Salmonella Typhimurium and Escherichia coli affected by bacterial cell history and water quality. Food Control 2017, 81, 137-146. [CrossRef]

36. Touchon, M.; Hoede, C.; Tenaillon, O.; Barbe, V.; Baeriswyl, S. Organised Genome Dynamics in the Escherichia coli Species Results in Highly Diverse Adaptive Paths. PLoS Genet. 2009, 5, e1000344. [CrossRef]

37. Landa, B.B.; Mavrodi, O.V.; Raaijmakers, J.M.; McSpadden Gardener, B.B.; Thomashow, L.S.; Weller, D.M. Differential ability of genotypes of 2,4-diacetylphloroglucinol-producing Pseudomonas fluorescens strains to colonize the roots of pea plants. Appl. Environ. Microbiol. 2002, 68, 3226-3237. [CrossRef]

38. Liu, D.; Cui, Y.; Walcott, R.; Chen, J. Fate of Salmonella enterica and enterohemorrhagic Escherichia coli cells artificially internalized into vegetable seeds during germination. Appl. Environ. Microbiol. 2018, 84, e01888-17. [CrossRef]

39. Gardner, T.J.; Fitzgerald, C.; Xavier, C.; Klein, R.; Pruckler, J.; Stroika, S.; McLaughlin, J.B. Outbreak of campylobacteriosis associated with consumption of raw peas. Clin. Infect. Dis. 2011, 53, 26-32. [CrossRef] 